\title{
Obraz lekcji z zakresu kształcenia językowego w gimnazjum
}

\section{The image of the lesson in the field of language training in a secondary school}

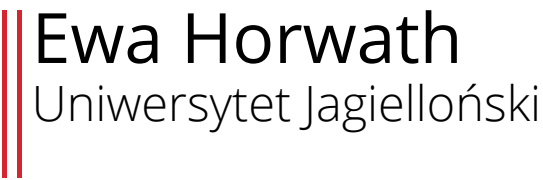

\begin{abstract}
The article presents the results of a research conducted within the Project "Polish language and literature didactics in a secondary school in the light of the new curriculum". The text is devoted to the ways how teachers work in the classroom on language training in secondary schools. The author analyzes material obtained during the observed and recorded lessons in representatively selected schools involved in the project. It includes not only the strategies, methods, techniques and teaching, but also interactions between teachers and students.
\end{abstract}

Key words: didactics, Polish language, linguistic training

Streszczenie: Artykuł przedstawia wyniki badań prowadzonych w ramach projektu IBE „Dydaktyka literatury i języka polskiego w świetle nowej podstawy programowej”. Tekst poświęcony jest sposobom pracy nauczycieli na lekcjach z zakresu kształcenia językowego w gimnazjum. Analizie poddano materiał uzyskany podczas obserwowanych i nagrywanych lekcji w wybranych reprezentatywnie szkołach, biorących udział w badaniach IBE. Uwzględniono nie tylko strategie, metody, techniki i pomoce dydaktyczne, ale także przebieg interakcji między nauczycielami a uczniami.

Słowa kluczowe: dydaktyka, język polski, kształcenie językowe

Poniższy tekst dotyczy sposobów pracy na lekcjach w gimnazjum, podczas których realizowane były cele i treści z zakresu kształcenia językowego. Przedstawione $\mathrm{w}$ artykule informacje i wnioski oparte są na badaniach prowadzonych $\mathrm{w}$ ramach projektu IBE „Dydaktyka literatury i języka polskiego w świetle nowej podstawy programowej" przez zespół pracujący w regionie obejmującym województwo małopolskie, podkarpackie, świętokrzyskie, lubelskie i mazowieckie². Analiza zgromadzonego materiału ma na celu poznanie, w jakim stopniu i w jaki sposób

1 Materiały $\mathrm{w}$ formie raportu z badań jakościowych znajdują się w dokumentacji projektu „Dydaktyka literatury i języka polskiego w świetle nowej podstawy programowej” złożonego w IBE w $2013 \mathrm{r}$. 
nauczyciele kształcą kompetencje językowe uczniów i próbują przezwyciężać ich trudności z tym kształceniem związane.

Analizie poddano 19 lekcji językowych, obserwowanych i nagrywanych przez badaczy we fragmentach lub w całości, a następnie opisanych przez nich według wcześniej ustalonych kryteriów. Przedstawione wnioski dotyczą zatem ograniczonego obszaru zajęć językowych, jednak próba dobrana została reprezentatywnie, w ramach badań wspomnianego projektu IBE. Nauczyciele mieli świadomość, że ich lekcje są nagrywane i będą poddawane analizie, więc najprawdopodobniej wybierali takie metody pracy i strategie traktowania materiału językowego, które ich zdaniem są najlepsze.

W formularzach prezentujących zajęcia znalazły się zapisy m.in. na temat zgodności tematu lekcyjnego z podstawą programową, programem nauczania i rozkładem materiału, zastosowanych metod i form pracy, przebiegu lekcji, wykorzystanych pomocy dydaktycznych, sposobu tworzenia notatki lekcyjnej, zadawanych prac domowych, formy kontrolowania i oceniania oraz utrwalania wiedzy i umiejętności. Obserwujący podawali informacje na temat aktywności uczniowskiej, notowali, czy na lekcjach rozwijano kompetencje komunikacyjne, kreatywność młodzieży, czy wprowadzana była indywidualizacja nauczania. Hospitujący lekcje oceniali postawy nauczycieli i uczniów, wskazywali, czy nauczyciel przygotowywał swoich wychowanków do samokształcenia, kształcenia ustawicznego. Do tych zapisów dodane zostały uwagi obserwatorów dotyczące zachowania uczniów i reakcji nauczycieli.

Zagadnienia omawiane na lekcjach to m.in. klasyfikacja głosek, rzeczowniki, zaimki, imiesłowy, wyrazy podzielne i niepodzielne słowotwórczo, neologizmy, związki frazeologiczne, rodzaje zdań złożonych, zróżnicowanie języka narodowego i style funkcjonalne.

\section{Strategie, metody, techniki dydaktyczne}

Do omówienia obserwowanych lekcji przyjęto strategie zaproponowane przez Wincentego Okonia, który, biorąc pod uwagę charakter działań lekcyjnych, wyróżnił cztery drogi nauczania i uczenia się: asocjacyjną, poszukującą, eksponującą, operacyjną i przyporządkował tym strategiom określone typy lekcji - podającą, problemową, waloryzującą i praktyczną (Okoń 2003, 320-324).

Do kształtowania sprawności językowych szczególnie przydatna bywa strategia operacyjna z typem lekcji praktycznej, podczas której uczniowie poznają cel działania, obserwują różnorodne fakty językowe, analizują je, wyciągają wnioski, aby poznać reguły, zasady i wzorcowe działania, a potem ćwiczyć się w sprawnym wykonywaniu zadań przez systematyczne ćwiczenia, odpowiednio urozmaicane, zakończone pracą domową sprzyjającą utrwaleniu sprawności. 
Wśród obserwowanych zajęć trudno byłoby wskazać takie, które całkowicie spełniałyby wymogi przywołanej strategii. Dominowały raczej lekcje podające, podczas których prezentowano i opracowywano nowe treści, czasem łącząc je z poprzednio nabytymi, a potem utrwalano poznane zagadnienia w kolejnych ćwiczeniach. Tylko dwa razy próbowano postawić problem. Było tak w przypadku rozważań nad rolą neologizmów w języku oraz opracowania na podstawie przykładowych materiałów charakterystycznych cech stylu tekstów użytkowych.

Na większości zajęć dominowało nastawienie na przekazywanie i utrwalanie wiedzy: określano typy głosek w wyrazie, analizowano rodzaje zdań, wyróżniano różne typy neologizmów, podawano przykłady różnych stylów funkcjonalnych itp. Nawet podczas lekcji prowadzonej według scenariusza koncentrującego się na funkcjonalności poznawanych form językowych, nauczyciel skupił się na wiedzy teoretycznej². Podczas lekcji o zaimkach eksponowany był podział tychże na rzeczowne, przymiotne itd., a nie zwracano szczególnej uwagi na funkcję, jaką pełnią te części mowy. Odpowiednie fragmenty poleceń zostały pominięte. Nauczyciel koncentrował się na tym, aby uczniowie poprawnie określili typ zaimków, kilkakrotnie poprawiał uczniów, którzy, zrozumiawszy, że zaimki zastępują określone części mowy, nazywali je rzeczownikowymi, przymiotnikowymi. Nazwy „rzeczowne”, „przymiotne” wprowadzone zostały kategorycznie, jako pewnik do zapamiętania, nie wykorzystano szansy na pokazanie umowności terminów, pojęć.

Niekiedy narzucanie terminów wiązało się z dość groteskowym tłumaczeniem, np. po odpowiedzi ucznia, że do mówienia potrzebne są struny głosowe, pojawiła się wypowiedź:

N: Struny głosowe to taka dosyć popularna nazwa, ale proponowałabym wam, żebyście jednak używali nazwy wiąadła głosowe. Dlaczego? Ano dlatego, że struny głosowe z czym się kojarza?

$\mathrm{U}: Z$ gitara.

N: Okazuje się, że ten narzad nie jest podobny do gitary...

Czasami, aby pokazać użyteczność wiedzy, nauczyciel odwoływał się do uczniowskich prac (Wykonywaliśmy ćwiczenia stylistyczne ostatnio, mówiliśmy, że często $w$ takich zdaniach $z$ podrzędnym przydawkowym popełniacie na wypracowaniach błędy).

Prawie każda z 19 lekcji rozpoczynała się od podania tematu lub przywołania definicji terminów i pojęć, którymi uczniowie mieli się zajmować. Tuż po sprawdzeniu listy obecności pojawiały się pytania zadawane kolejno po jednowyrazowych odpowiedziach uczniów (czasem chóralnych), np. Jakie znamy pojęcia ze słowotwórstwa? Co to jest formant?

Na kilku lekcjach nauczyciel odpytywał z wiedzy pozyskanej na zajęciach wcześniejszych. np.:

2 Lekcja prowadzona była z wykorzystaniem podręcznika Horwath E., Kiełb G., 2009, Bliżej słowa, Warszawa, s. 122. i powiązanego z nim poradnika metodycznego dla nauczycieli. 
N: Co było na zadanie?

U: Przypomnieć sobie o zdaniach współrzędnie złożonych.

$\mathrm{N}$ : Wobec tego przypomnijmy sobie, jakie mamy rodzaje zdań współrzędnie złożonych?

lub

N:. Proszę szybciutko, czym zajmuje się fonetyka?

U: To, co słyszymy.

N.: Niech tak będzie.

kolejny U: Dział nauki zajmujacy się głoskami.

$\mathrm{N}$ : Co to jest głoska?

W fazie wprowadzającej lekcji dominowały metody podające. Do opisu metod i ćwiczeń przyjęto podział proponowany przez Marię Nagajową (1990, 32-39, 67). Na obserwowanych lekcjach najczęściej stosowano pogadankę podającą. Stawiano pytania odwołujące się do wiedzy uczniów, nie zawsze jasno sformułowane, np. Wyraz „stolik” jest wyrazem jakim? Nauczyciele często nie wykorzystywali podanych przez uczniów odpowiedzi, nie odnosili się do nich, a zadawali kolejne pytania, które miały prowadzić do uzyskania zakładanej przez nich odpowiedzi, np. Stolik pochodzi od wyrazu stół, zatem stolik jest jakim wyrazem?.

Prowadzący lekcje zazwyczaj nie dawali uczniom czasu na przemyślenie odpowiedzi i sami odpowiadali na własne pytania.

W 12 z obejrzanych lekcji zastosowano krótkie wykłady, w których nacisk położony był na przedstawienie teorii dotyczącej omawianego zagadnienia językowego.

Ten etap lekcji zamykała notatka, najczęściej dyktowana przez nauczyciela lub podana w formie gotowej na kartce (ponad 60\% lekcji), na 6 lekcjach formułował ją tylko nauczyciel, na 6 kolejnych notatka była współtworzona przez uczniów i nauczyciela, przy czym wkład uczniowski ograniczał się zwykle do podania jednowyrazowych przykładów. Na żadnej z obserwowanych lekcji uczniowie nie tworzyli jej sami. Na kilku zajęciach nie zapisywano żadnych notatek.

Nauczyciele zazwyczaj upewniali się, czy uczniowie rozumieją treść przekazu, czy jasne są dla nich pytania, polecenia. Jedynie w 5 przypadkach nie było to sprawdzane. Niekiedy nauczyciel prosił o przeczytanie definicji z podręcznika.

W 17 przypadkach do kolejnego ogniwa lekcji włączano ćwiczenia, które uczniowie wykonywali bądź wspólnie, bądź indywidualnie. Maria Nagajowa wyróżniła ćwiczenia gramatyczne, uczące obserwacji i analizy gramatycznej, oraz ćwiczenia językowe, służące doskonaleniu sprawności językowej (Nagajowa 1994, 15).

Ćwiczenia, które zarejestrowano, w większości nastawione były na utrwalanie teoretycznej wiedzy. Na przykład podczas zajęć o imiesłowach uczniowie całą lekcję określali ich formy, a zajęcia o różnych typach 
zdań dotyczyły całogodzinnych analiz schematów składniowych pokazywanych na wykresach. Nawet polecenia zadań podręcznikowych były zmieniane w tym kierunku, np. Prosze bardzo, zadanie nr 10, tutaj sobie zmodyfikujemy polecenie: oddzielamy zdania, zaznaczamy spójniki, nazywamy i dopasowujemy wykres.

Sporadycznie (na pojedynczych lekcjach) uczniowie wykonywali ćwiczenia gramatyczno-stylistyczne i ćwiczenia redakcyjne. Częściej obserwowano ćwiczenia słownikowe i frazeologiczne. Czasem prowadzący zajęcia w sposób mechaniczny przechodził od wykładu czy pogadanki do wykonywania ćwiczeń w podręczniku lub w zeszycie ćwiczeń (A teraz otwieramy podręcznik na stronie...). Nauczyciele nie wyjaśniali istoty ćwiczeń, skupiając się na podaniu strony czy przeczytaniu polecenia. Zanotowana $\mathrm{w}$ formularzach obserwacyjnych informacja o pracy samodzielnej uczniów wskazywała w większości na indywidualne wykonywanie ćwiczeń (prawie $50 \%$ lekcji), które następnie były wspólnie sprawdzane. Niekiedy za pracę samodzielną uznawano pracę parami przy wykonywaniu zestawu zadań z podręcznika lub zeszytu ćwiczeń.

Tylko podczas jednej lekcji nauczyciel próbował wyzwolić kreatywność uczniów. Była to próba podawania własnych neologizmów odnoszących się do określonej rzeczywistości. Polecenie Ruszyć tak głowa, dać upust wyobraźni zostało entuzjastycznie przyjęte przez uczniów, którzy nie tylko z chęcią pracowali, ale i z zainteresowaniem wysłuchiwali propozycji kolegów, aktywnie je komentując. Ta część lekcji korzystnie się wyróżniała na tle heurystycznego początku i ćwiczeń wstępnych z zakresu słowotwórstwa. Na pozostałych lekcjach nie były podejmowane takie próby. Osoby sporządzające raport z lekcji notowały w swoich komentarzach, że była to lekcja językowa, a więc lekcja nienadająca się na ćwiczenie kreatywności. Powszechne jest - jakże błędne - przekonanie, że twórczość, nawet tę szeroko pojętą, wyzwalać można jedynie na lekcjach literackich. Propozycje twórczych działań zawarte w artykułach czy poradnikach metodycznych są przez nauczycieli pomijane (Horwath 2012, 380).

Zadania, które z powodzeniem wystarczyło ustnie omówić, przeciągano, każąc uczniom przepisywać przykłady z podręcznika do zeszytu. Nierzadko łatwe ćwiczenie wykonywane było właściwie dwukrotnie: raz - samodzielnie przez ucznia, a następnie podczas wspólnego omawiania w klasie. O ile taki sposób sprawdza się przy zadaniach trudniejszych, wymagających złożonego myślenia, zakładających pewną kreatywność, o tyle mechaniczne przekształcania, uzupełniania, sprawdzane częściowo przez nauczyciela podczas wykonywania ćwiczeń przez młodzież powtórzone w głośnym odczytywaniu przykładu jest stratą czasu, którego później brakuje na kształcenie innych umiejętności.

Ćwiczenia przygotowywane przez nauczycieli zawierały czasem przykłady niewłaściwie dobrane, mało wyraziste, niejednoznaczne, np. uczniom trudno było zrozumieć treść i zakres wyrazów, gdy w zadaniach pojawiały 
się słowa o wielu znaczeniach, także przenośnych. Nauczyciel tracił czas na żmudne, nie zawsze jasne wyjaśnienia, które odbierały uczniom chęć do pracy. Niekiedy wykorzystywane teksty literackie, np. podczas lekcji o neologizmach, były zbyt trudne dla uczniów.

Brakowało poleceń skłaniających uczniów do myślenia, a także pytań ukierunkowujących na analizę materiału, obserwację, która prowadziłaby do samodzielnych wniosków.

Z ankiet i wywiadów przeprowadzanych z uczniami wynika, że określanie form gramatycznych wyrazów oraz przekształcanie zdań według podanego kryterium to typ zadań najmniej lubiany przez uczniów, a nauczyciele deklarują, że rzadko stosują ćwiczenia typu rysowanie wykresów. Natomiast na lekcjach hospitowanych, często też nagrywanych, a więc w dużym stopniu pokazowych, takie formy dominowały. Nic dziwnego, że w klasach starszych wzrasta wśród uczniów niechęć do lekcji językowych.

Utrwalanie materiału w 85\% nastawione było na wiedzę, zarówno to wprowadzane w trakcie lekcji jako podsumowanie pewnej jej części, jak i na koniec zajęć. Na przykład nauczyciel po wygłoszeniu wykładu na temat narządów mowy i powstawania głosek prosi uczniów, aby powtórzyli, jakie mamy narządy mowy, jak powstaje głos. Na zakończenie lekcji podobne polecenie (Patrycja, proszę powiedz, jaka jest różnica i które narzady mowy sa ważne, gdy powstaja głoski dźwięczne i bezdźwięczne... Przy powstawaniu głosek dźwięcznych i bezdźwięcznych który narząd jest najważniejszy? Jeżeli wiązadła sq zsunięte to... Proszę powiedzieć: samogłoski sa dźwięczne czy bezdźwięczne itd.). Charakterystyczna jest wypowiedź innego nauczyciela: Żebyście te informacje, które zrobiliśmy na lekcji, opanowali, nauczyli się tego... Ćwiczenia rozwijające umiejętności pojawiały się w znacznie rzadziej.

Jolanta Nocoń wskazuje na trzy wymiary funkcjonalnego rozwijania świadomości językowej uczniów: wewnątrzsystemowej, wewnątrztekstowej i zewnątrztekstowej (Nocoń 2014,167).

Podstawa programowa kładzie duży nacisk na rozumienie funkcji rozmaitych środków językowych. Tej funkcjonalności zupełnie zabrakło w ponad jednej trzeciej obserwowanych zajęć. Jeżeli w ćwiczeniach wykonywanych przez uczniów można było zauważyć funkcjonalność, dotyczyła ona wiedzy metajęzykowej, zadania obejmowały przede wszystkim operacje na jednostkach języka, rzadziej operacje na tekście.

Nauczyciele na lekcjach, na których - zdaniem hospitujących - wiedza o języku była funkcjonalizowana, zazwyczaj proponowali ćwiczenia polegające na przekształcaniu wyizolowanych zdań lub redagowanie różnych form użytkowych, nie zawsze ściśle powiązanych z istotą środka językowego, o którym była mowa na zajęciach (np. temat lekcji: Zakres i treść wyrazów, a potem notatka informacyjna pisana przez uczniów bez wykorzystania hiperonimów). 
Na brak funkcjonalności wskazywały już tematy lekcyjne, nastawione tylko na przekazywanie informacji o zagadnieniach lekcyjnych (Rozróżniamy i analizujemy zdania złożone; Co to jest imiesłów?; Co to jest zakres i treść wyrazów; Zróżnicowanie języka narodowego itp.). Nawet jeżeli temat brzmiał funkcjonalnie, np. Stosujemy zwiazki frazeologiczne $w$ wypowiedziach, to na lekcji dominowała teoria; uczniowie definiowali związek frazeologiczny, wysłuchiwali wykładu nauczyciela na temat różnych rodzajów związków frazeologicznych, zapisywali dyktowaną przez nauczyciela notatkę, rozpoznawali rodzaje frazeologizmów i tylko jedno zadanie dotyczyło wprowadzania do tekstu omawianych związków wyrazowych.

Niekiedy nauczyciel wyraźnie wskazywał teoretyczny cel lekcji, a podręcznikowe definicje były wręcz kluczowym słowem, np. Drodzy Państwo, dziś lekcja z zakresu gramatyki i nauki o języku. Moi drodzy, dowiecie się, co to jest treść i zakres wyrazu. $Z$ tym pojęciem zwiazana jest definicja - definicja słownikowa wyrazu, ale pamiętamy, że oprócz tych definicji słownikowych, które mamy, z którymi się spotykamy nie tylko na lekcjach języka polskiego, mieliśmy $w$ ubiegłym roku pojęcie definicji słowotwórczej. Proszę mi powiedzieć, co to było. Jak definiowaliśmy to pojęcie „definicja słowotwórcza"?

Większość nauczycieli zadało pracę domową, tylko 4 prowadzących nie zrobiło tego (w tym 1 osoba w związku z prośbą uczniów o niezadawanie prac przed świętami). Prawie 50\% nauczycieli upewniało się, czy polecenie zostało zrozumiane przez uczniów. Żaden nauczyciel nie wskazał na dodatkowe źródła, z których uczniowie mogliby skorzystać, wykonując pracę domową. Tylko dwie osoby sformułowały zadania do wyboru, nie było to jednak związane $\mathrm{z}$ indywidualizacją nauczania ze względu na zainteresowania uczniowskie, a jedynie wskazano możliwość wykonania dodatkowego ćwiczenia przez chętnych.

Ponad 35\% nauczycieli na początku kolejnej lekcji sprawdzało zadanie domowe, omawiając całość lub fragmenty prac. To mogłoby być bardzo dobrym wprowadzeniem, gdyby tematy mocniej sfunkcjonalizować i powiązać z zagadnieniami kolejnych zajęć.

Podsumowując ten wywód, można stwierdzić, że najczęściej podczas jednogodzinnych zajęć łączone były: wykład, pogadanka podająca lub heureza, metoda ćwiczeniowa (prawie 50\% lekcji było tak poprowadzonych), w drugiej kolejności: heureza i wykonywanie ćwiczeń (ponad 25\%). Dwa razy zaobserwowano namiastki dyskusji.

Wprowadzane też były działania określane jako „inne”. Do nich zaliczano na przykład rozwiązywanie zagadek, pracę z kartą ćwiczeń przygotowaną przez nauczyciela. Charakterystyczne jest, że ta trochę atrakcyjniejsza forma też wykorzystywana była do zadań o charakterze teoretycznym (np. grupowanie w różnych woreczkach określonych typów frazeologizmów). 
Ani raz nauczyciele nie wprowadzili na lekcjach językowych dramy, debaty, happeningu czy WEBQuestu. Takich form nie było na lekcjach prowadzonych przez nauczycieli zarówno z długim, jak i krótkim stażem pracy.

Słabo wypada również przygotowanie uczniów do samokształcenia i kształcenia ustawicznego. Tylko 1/3 nauczycieli próbuje podczas lekcji językowych wprowadzać zadania wymagające od uczniów samodzielności w poszukiwaniu i przetwarzaniu informacji (jest to najczęściej związane jedynie z korzystaniem ze słownika, by odszukać $w$ nim znaczenie wyrazu).

\section{Wykorzystywane pomoce}

$\mathrm{Na}$ ponad 50\% obserwowanych lekcji wykorzystywano podręcznik, na ponad 35\% - zeszyt ćwiczeń. Podręcznik stosowano w połączeniu z ćwiczeniami, zarówno zaproponowanymi przez wydawnictwo (ponad 25\% lekcji), jak i nauczycielskimi (ponad 15\% lekcji).

Ćwiczenia z podręcznika nie zawsze wykorzystywane były zgodnie z poleceniami, na przykład zadanie związane z pytajną funkcją zaimków przekształcone zostało przez nauczyciela w działania polegające na określaniu, jaką część mowy zastępuje określony zaimek „kto?”, „czego?”, „jaki?”, „ile?” itd. Zdarzało się też, że fragmenty podręcznika, na polecenie nauczyciela, odczytywane były na głos przez uczniów, a informacje w nim podane młodzież przepisywała do zeszytu.

Podczas zajęć, na których nie korzystano z podręcznika, nauczyciele wprowadzali ćwiczenia z poradników metodycznych (prawie 50\%) lub - jak deklarowali - wykorzystywali propozycje własne (prawie 50\%). Najczęściej było to pisanie samodzielnych krótkich tekstów lub rozpoznawanie wskazanych zjawisk językowych.

Podręcznik w całości nadał kształt lekcji tylko w jednym przypadku, na pozostałych zajęciach jedynie w pewnym stopniu wpływał na ich przebieg.

Lekcje, które w przeważającej części ukształtowane były przez podręcznik lub zeszyt ćwiczeń, wywoływały największe znużenie u uczniów, dlatego że nauczyciel zlecał je mechanicznie, wyglądało to mniej więcej tak: teraz ćwiczenie pierwsze, teraz drugie, przechodzimy do ćwiczenia 3. Na ogół nie zaobserwowano zmienności form ćwiczeń, dynamizowania zajęć przez różnorodne techniki ich wykonywania. Zazwyczaj uczniowie wykonywali zadania wspólnie lub pracowali samodzielnie, a potem, odczytując przykłady na głos, sprawdzano poprawność wykonania zadań.

Tylko na 4 lekcjach pojawiły się słowniki, z których pojedynczy uczniowie korzystali w niewielkim wymiarze. Na żadnej z lekcji nie pokazywano możliwości słowników elektronicznych, a takie ćwiczenia w dobie cyfryzacji wydają się konieczne. 
Raz zastosowano planszę ze schematem i raz narysowano schemat poglądowy na tablicy. Nauczyciele traktowali te pomoce jako elementy poglądowe wykładu, a następnie prosili uczniów o przepisanie i przerysowanie schematów do zeszytu. Tracono w ten sposób kolejne minuty lekcji, które można było poświęcić na ćwiczenie umiejętności wskazanych w podstawie programowej.

Prezentacja komputerowa przygotowana przez jednego tylko nauczyciela miała charakter wykładowy, nauczyciel czytał informacje przedstawiane na kolejnych slajdach, a uczniowie przepisywali je do zeszytu.

Doświadczenia związane $\mathrm{z}$ przygotowywaniem narzędzi dydaktycznych w ramach projektu IBE oraz opinie uczniów wyrażane w wywiadach przeprowadzonych $\mathrm{w}$ ramach projektu dowodzą, że stosowanie nowych technologii jest nie tylko atrakcyjne dla uczniów, ale przede wszystkim skuteczne w nauczaniu. Nauczyciele również wskazują na przydatność takich narzędzi, niestety, jak pokazały badania, nie stosują ich w praktyce szkolnej (Handzel 2015, 98).

Teksty literackie spoza podręcznika wykorzystały nauczycielki prowadzące lekcje o neologizmach artystycznych. W trakcie hospitacji dało się zauważyć, że zajęcia językowe, które choć trochę powiązane były z literaturą, wzbudzały większe zainteresowanie uczniów. Idea takich zajęć od lat propagowana jest przez Jadwigę Kowalikową, ale w praktyce szkolnej zasada integracji nadal gości nieczęsto (Kowalikowa 2004, 122-124). Zdarzało się, że nawet jeżeli nauczyciel opierał się na materiale dodatkowym (na przykład korzystał ze zbioru przysłów), traktował go czysto instrumentalnie, do wskazywania np. zdań nadrzędnych i podrzędnych.

Nikt z prowadzących lekcje nie sięgnął do tekstów publicystycznych, reprodukcji malarskich czy innych tekstów kultury, a przecież można je wykorzystywać w różnorodny sposób również do kształcenia sprawności językowych (Horwath 2015, 255). Jedna z nauczycielek, która prowadziła lekcję według scenariusza z poradnika metodycznego, pominęła wszystkie zaproponowane tam materiały ikonograficzne, filmowe czy muzyczne, przewidziane do realizacji lekcji, chociaż dysponowała sprzętem, który bez problemu mogła uruchomić podczas zajęć.

\section{Przebieg interakcji}

Podczas obserwowanych lekcji dominowała aktywność nauczyciela, co widać choćby w transkrypcjach lekcji, w których kolumna poświęcona wypowiedziom uczących jest zdecydowanie większa niż kolumna z wypowiedziami młodzieży. Uczniowskie odpowiedzi były najczęściej jednowyrazowe. Nic dziwnego, skoro co najmniej połowa pytań wymagała tylko odpowiedzi „tak” lub „nie”. Nauczycielom najczęściej nie starczało cierpliwości, żeby dać uczniowi czas do namysłu i podpowiadali, wskazując 
miejsce w podręczniku, gdzie znajduje się pożądane słowo (np. żeby zastapić to słowo powtarzające się to stosujemy właśnie, co? W rameczce Magda to mamy).

Niekiedy stawiano pytania, które prowadziły uczniów do błędnych wniosków, np.

$\mathrm{N}$ : Smuga, jaka to jest część mowy?

$\mathrm{U}:$ Rzeczownik.

$\mathrm{N}$ : Rzeczownik, czyli widzimy, że pierwszy wniosek jest następujący. Kto ten pierwszy wniosek sformułuje?

U: Neologizmy powstaja od rzeczownika.

$\mathrm{N}$ : Że neologizmy $z$ wiersza jakiego?

U: Śnica i śniegowica.

N: Śnica i śniegowica w jaki sposób zostały utworzone?

$\mathrm{U:} \mathrm{Od} \mathrm{rzeczownika.}$

N: Od rzeczowników. Sa to formy odrzeczownikowe.

Zadawane pytania miały często charakter retoryczny (A jak piszemy wypracowania, to potrzeba myśleć logicznie?) lub konstrukcję podwójną, przypominającą dwuelementowe testy wyboru, np. A czy logiczne myślenie jest nam potrzebne na co dzień, czy tylko na lekcjach?; Czy to jest imiesłów czynny, czy bierny?.

Pytania często zawierały $\mathrm{w}$ sobie podpowiedź, np. Proszę powiedzieć mi, w jakich wyrazach możemy wydzielić formant i podstawe słowotwór$c z a, w$ wyrazach podstawowych czy $w$ wyrazach pochodnych?

Zdarzały się pytania niejasne. Nawet biorąc pod uwagę kontekst sytuacyjny, uczeń po usłyszeniu polecenia: Jaka funkcję pełnia zaimki $w$ tych $z$ daniach $w$ stosunku do tych pierwszych, nie ma szans na udzielenie odpowiedzi. Po zadaniu nieprecyzyjnych pytań, np.: Co możemy zrobić $z$ wyrazem góra?; Jak się wypowiadamy? nauczyciele dodawali kolejne pytanie lub odpowiadali sobie sami, np. N: Jakie sa względem siebie te zdania? $\mathrm{N}$ : Wspót-rzęd-ne. Nie pytamy żadnym zdaniem o inne. Zgadza się?

Często nauczycielska odpowiedź była narzucana jako jedyna poprawna, choć można było przyjąć i uczniowską. Na pytanie Zgadzacie się? uczniowie reagują w jednoznaczny sposób - milczeniem lub nic niewnoszącym „tak”. Stawianie nieprecyzyjnych lub źle sformułowanych pytań powodowało też konieczność długich, nużących wyjaśnień, które sprawiały, że uczniowie nie pamiętali polecenia wstępnego.

Czasami wypowiedzi nauczyciela nie do końca były prawdziwe, np. Zapamiętajcie sobie, $\dot{z} e$ nazwy żeńskie pochodza zawsze od nazw męskich. Wystarczy, że uczeń przywoła wyraz przedszkolanka, żeby w klasie wywołać konsternację. Niekiedy zaobserwować można było potknięcia metodyczne związane z niewykorzystaniem wiedzy językoznawczej, np. nauczyciel prosił, aby nosowość głoski ą zauważyć, wymawiając ją porównawczo $\mathrm{z}$ a, potem to samo polecenie dotyczyło ę i e. Uczniowie nie dostrzegali różnic między głoska nosową i ustną, nie potrafili więc 
wykonać ćwiczenia ani odpowiedzieć na pytanie nauczyciela, który nie wziął pod uwagę, że samogłoski nosowe wymawiane są często dyftongicznie, a więc uczniowie nie mogli znaleźć odpowiedzi. Zdarzało się też, że mylący okazywał się temat, np.: Komu $w$ drogę, temu czas. Zdanie złożone $z$ podrzędnym dopełnieniowym.

Niekiedy nie wiadomo było, jaki był cel stawianych pytań (np. Czy to ostatnie ćwiczenie o śwince można nazwać ćwiczeniami redakcyjnymi?).

Podczas lekcji nauczyciele systematycznie kontrolowali zadania wykonywane w klasie; było to zarówno indywidualne przejrzenie wykonywanych ćwiczeń w zeszytach, jak i wspólne odczytywanie wypełnionych ćwiczeń. Najczęściej słownie oceniano propozycje uczniów (2/3 hospitowanych zajęć), na 1/3 oglądanych lekcji takich opinii nie wyrażano w ogóle. $\mathrm{Na}$ żadnej z obserwowanych lekcji nie zauważono elementów samooceny uczniowskiej.

Uczniowie na każdej z obserwowanych lekcji, mimo że niewiele mówili, popełniali błędy językowe. Ponad 35 nauczycieli w ogóle ich nie poprawiało, choć zwrócenie uwagi nie przerwałoby uczniowi całościowej wypowiedzi. Pozostawienie bez komentarza uczniowskich błędów typu: bo nie wszyscy rozumia ten tekst; mi się wydaje, że to jest zawód - może dziwić, zwłaszcza że w ankietach nauczyciele $\mathrm{w}$ większości deklarowali poprawianie usterek językowych uczniów.

80\% nauczycieli nie wprowadzało żadnej indywidualizacji nauczania. Ci, którzy to robili, najczęściej skupiali się na podejściu do ucznia słabiej radzącego sobie i wyjaśnieniu mu istoty polecenia. Niekiedy nauczyciel wskazywał słabszym uczniom tekst w podręczniku, który wyjaśniał niezrozumiałe zagadnienie. Nie widać było żadnej pracy z uczniem zdolnym. Zdarzało się jedynie, że nauczyciele wybierali lepszych uczniów do wykonywania przykładowych zadań na tablicy po to m.in., żeby dać wzór do samodzielnej pracy nad kolejnymi częściami ćwiczenia.

Ponad połowę zajęć prowadzono bez motywowania uczniów do słownej aktywności. Niepokojące jest, że w $20 \%$ przypadków pedagodzy, mimo podejmowanych prób, nie potrafili zaaktywizować uczniów. Uczniowie zgłaszali się najczęściej, gdy polonista pytał o elementy wiedzy teoretycznej. Byli do tego przyzwyczajeni i takie zadania były dla nich łatwiejsze. Wydaje się, że na aktywność uczniowską wpływał temat zajęć i dobór materiałów. Jeżeli były one ciekawe, uczniowie sami zgłaszali się do odpowiedzi.

Zupełnie nie brano pod uwagę zainteresowań młodzieży, a czasem wręcz odrzucano aktywność związaną z przywoływaniem przykładów o tematyce, która wyraźnie uczniów interesowała, natomiast nie była przewidziana przez nauczyciela do wprowadzenia (np. podczas lekcji o zakresie i treści wyrazów uczniowie podawali przykłady z dziedziny sportu i zaczynali nad nimi się zastanawiać, ale nauczyciel zamykał dyskusję i przechodził do przykładów przygotowanych przez siebie, które uczniów mniej interesowały). 
Na ponad 50\% lekcji uczniowie nigdy nie inicjowali dyskusji. Na pozostałych - robili to bardzo rzadko lub rzadko. Nic dziwnego, skoro charakterystyczne dla obserwowanych lekcji językowych było ich prowadzenie metodami, które nie aktywizowały uczniów. Natomiast, jak zaznaczali obserwatorzy, w 50\% uczniowie często lub bardzo często włączali się do dyskusji zainicjowanej przez nauczyciela, choć bardzo szybko taka rozmowa była kierowana na tematy założone przez nauczyciela i wtedy pojawiały się tylko odpowiedzi na pytania zadane przez prowadzącego.

Mało atrakcyjne formy lekcji nie sprzyjały zaangażowaniu uczniów. $\mathrm{W}$ tak zaplanowanych zajęciach nie było miejsca na istotne pytania czy też refleksje na temat języka. Pracując w ten sposób, trudno osiągnąć sukces. Zwykle po 20 minutach narastało znużenie uczniów, którzy nawet przed kamerami nie ukrywali swoich negatywnych emocji. Na jednym z filmów widać ziewanie, drapanie się po głowie, rozmowy, jedzenie (najpierw ukradkiem, potem wręcz demonstracyjnie jawnie). Osoba wypełniająca formularz jednej z lekcji napisała w komentarzu: Kilkoro uczniów na wieść o kolejnym zadaniu przykłada ręke do czoła - wyglądaja na bardzo znużonych. To między innymi wynik tego, że ćwiczenia realizowane z podręcznika prowadzone były zawsze w tej samej formie.

\section{Podsumowanie}

Podobne badania prowadzone przez dwa kolejne zespoły z pozostałych regionów Polski potwierdzają, że umiejętności językowe gimnazjalistów rozwijane są w ograniczonym zakresie ${ }^{3}$. Widać to szczególnie wyraźnie podczas analizy zadań testowych wykonywanych przez uczniów w ramach projektu. Zdobyta przez nich wiedza o języku była słabo wykorzystywana do tworzenia tekstów własnych (ponad 80\% uczniów nie otrzymało punktów za poprawność językową swoich prac). Obserwatorzy zanotowali, że na prawie $90 \%$ lekcji językowych uczniowie mają okazję wykorzystać wiedzę w praktyce i kształcić praktyczne umiejętności językowe. Niestety, sprowadza się to najczęściej do podawania własnych przykładów ilustrujących omawiane zagadnienie lub do napisania wskazanej przez nauczyciela formy użytkowej, nie zawsze ściśle powiązanej z funkcją środków językowych, o których była mowa na zajęciach.

Analiza opisów obserwowanych lekcji językowych skłania do stwierdzenia, że kształcenie językowe w szkołach gimnazjalnych nie zawsze jest zgodne z zapisami podstawy programowej. Uczniowie nie są motywowani do myślenia, co gorsza (jak wynika z ankiet), przyzwyczajają się do mechanicznego wypełniania ćwiczeń i traktują takie zadania jako naturalne, nie wyobrażając sobie, że lekcje językowe mogłyby być poprowadzone inaczej. Brak działań twórczych, brak nastawienia na ćwiczenie umiejętności

3 Wnioski dotyczące kształcenia językowego zawarte są w raporcie końcowym projektu na stronie http://docplayer.pl/2954051-Dydaktyka-literatury-i-jezyka-polskiego-w-gimnazjum-w-swietle-nowej-podstawy-programowej-raport-z-badania.html. 
komunikacyjnych powodują, że uczniowie nie widzą celu w drobiazgowej analizie form i konstrukcji językowych i w przyswajaniu terminów językoznawczych. Natomiast rozmowa o zjawiskach językowych bliskich uczniom pobudza myślenie i zwiększa chęć rozmowy o językowej rzeczywistości.

Mimo że uczniowie (jak deklarują) w większości lubią przedmiot język polski, to ich zachowanie podczas lekcji językowych wskazuje na obojętność lub znużenie. W trakcie wywiadów pogłębionych gramatykę i ortografię wymieniali oni jako jedyne „słabe” punkty lekcji języka polskiego.

Na podstawie obserwacji zgromadzonego materiału można stwierdzić, że korzystanie z podręczników i zeszytów ćwiczeń pozwala łatwiej wprowadzać funkcjonalne nauczania języka, gdyż pomoce te zawierają materiał inspirujący do kształcenia różnych umiejętności językowych, między innymi sprawności komunikacyjnych. Natomiast niebezpieczną tendencją jest zmienianie przez nauczycieli poleceń podręcznikowych na takie, które kładą nacisk na wiedzę teoretyczną. Niepokoi też mechaniczne wręcz wykonywanie poleceń, bez odwoływania się do istoty zagadnień, które były przedmiotem lekcji. Należałoby również wyeliminować dyktowanie notatek lekcyjnych przez nauczyciela lub wręcz przepisywanie fragmentów podręcznika, gdyż te działania nie przyczyniają się do realizacji wymagań podstawy programowej. Warto również zwiększyć udział uczniów w tworzeniu notatek, aby ćwiczyć umiejętności tekstotwórcze. Zadania domowe powinny odwoływać się do problemów językowych nurtujących uczniów, a nie być tylko utrwalaniem wiedzy poznanej podczas zajęć lekcyjnych. Warto też zwrócić uwagę, że lekcje językowe mogą służyć wyzwalaniu aktywności, wyobraźni i kreatywności uczniów.

Nie sposób przecenić roli lekcji językowych, bo przecież umiejętności zdobyte podczas tych zajęć powinny poszerzać możliwości odczytywania złożonych komunikatów, umożliwiać uczniom sprawne analizowanie i interpretowanie tekstów kultury, tworzenie własnych tekstów. Lekcje językowe mogą też wychowywać, uczyć kultury dyskusji, umiejętności wzajemnego słuchania się. Trudno jednak te wartości wprowadzać, jeżeli dominującą metodą staje się heureza (nie zawsze właściwie prowadzona), wykład czy - często mechaniczne i bezrefleksyjne - wypełnianie ćwiczeń językowych nastawionych na wiedzę o języku.

\section{Bibliografia:}

Biedrzycki Krzysztof, Bordzoł Piotr, Hącia Agata, Kozak Wioletta, Przybylski Błażej, Strawa Ewelina i Wróbel Iwona, 2015, Dydaktyka literatury i języka polskiego $w$ gimnazjum $w$ świetle nowej podstawy programowej, Warszawa.

Handzel Agnieszka, 2015, Prezentacja multimedialna na lekcji języka polskiego, w: Janus-Sitarz A., Handzel A., Kania A., Kulig A. (red.), Trudne lekcje języka polskiego. Ku rozwiązaniom praktycznym, Kraków. 
Horwath Ewa, 2012, O twórczości uczniowskiej na lekcjach językowych, w: Niesporek-Szamburska B. (red.), Wiedza o języku i kompetencje językowe uczniów, Katowice.

Horwath Ewa, 2015, Rola ilustracji w kształceniu językowym. Wskazówki, przykłady ćwiczenia, w: Pilch A., Rusek M. (red.), Ikoniczne i literackie teksty w przestrzeni nowoczesnej dydaktyki, Kraków.

Kowalikowa Jadwiga, 2004, Kształcenie językowe. Teoria dla praktyki, w: JanusSitarz A. (red.), Polonista $w$ szkole. Podstawy kształcenia nauczyciela polonisty, Kraków.

Nagajowa Maria, 1990, Abc metodyki języka polskiego, Warszawa.

Nagajowa Maria, 1994, Nauka o języku dla nauki języka, Warszawa.

Nocoń Jolanta, 2014, Świadomość językowa w podręcznikach szkolnych, w: Nocoń J., Tabisz A. (red.), Język a Edukacja. Świadomość językowa, Opole.

Okoń Wincenty, 2003, Wprowadzenie do dydaktyki ogólnej, Warszawa.

\section{O Autorce:}

Ewa Horwath - adiunkt w Katedrze Polonistycznej Edukacji Nauczycielskiej na Wydziale Polonistyki UJ. Zajmuje się przede wszystkim dydaktyką języka. Jest autorką dwóch cykli podręczników do szkoły podstawowej (Słowa z uśmiechem) i gimnazjum (Bliżej słowa) oraz kilkudziesięciu poradników metodycznych dla nauczycieli. Publikuje artykuły przybliżające nauczycielom wiedzę językową oraz nowoczesne i kreatywne sposoby nauczania. 